\title{
The Banality of Cynicism: Foucault and the Limits of Authentic Parrhēsia
}

\author{
GORDON HULL \\ University of North Carolina at Charlotte, USA
}

\begin{abstract}
Foucault's discussion of parrhēsia - frank speech - in his last two Collège de France lecture courses has led many to wonder if Foucault is pursuing parrhēsia as a contemporary strategy for resistance. This essay argues that ethical parrhessia on either the Socratic or Cynical model would have little critical traction today because the current environment is plagued by problems analogous to those Plato thought plagued Athenian democracy. Specifically, authentication of parrhesiasts as a technique for authenticating their speech - the specific problem that the move to ethical parrhessia in ancient Greece was designed to solve - becomes intractable in a social media environment, even with the added Cynical move to pure visibility. The problem is that contemporary society overproduces visibility as a condition for participation, which means that the context for authenticating parrhesiastic speech is one in which visibility is banalized and in which there is a surplus of speech which presents as parrhesiastic. The problem of authentication is thus a serious one, one which social media makes particularly intractable.
\end{abstract}

Keywords: Foucault, parrhesia, speech, cynicism, biopower, social media, Facebook, visibility, authenticity.

The publication of Foucault's lectures on parrhēsia - roughly, frank speech that puts the speaker at considerable risk - invites a general reassessment of his late work. ${ }^{1}$ In particular, it shows that Foucault's interest in techniques of ethical stylization in ancient thought was accompanied by an interest in ancient critical practices as well. Current public revelations about the role of Facebook and other social media in the 2016 U.S. presidential election invite consideration of the ways that parrhessia and other critical speech practices might function today, in a context where large numbers of people interact with politics largely through Facebook and other social media platforms. In other

\footnotetext{
1 "Parrhesiasts are those who undertake to tell the truth at an unspecified price, which may be as high as their own death." Michel Foucault, The Government of Self and Others: Lectures at the Collège De France, 198283 [1983] (2008), 56 (see also 299-301).
} 
words, the intersection of these events enables one to consider them together as a moment of that reassessment.

A number of factors complicate this consideration. First, Foucault's account of Greek parrhēsia makes clear that it was not a unitary phenomenon. There were at least three versions: a Pre-Socratic, political one, in which parrhēsia is presented as the duty of the citizens of democracy; a Socratic, ethical one, in which political parrhēsia fails and becomes an ethical practice with political implications; and a third, Cynical version, which radicalizes many of the attributes of the Socratic one. The latter two versions are united by a concern with the authenticity of the speaker, a concern that is masked in the first phase by the limited franchise in Greek democracy. Second, because Foucault discusses the transition from ethical to political parrhēsia in the context of Plato's Socrates, any discussion of that transition will necessarily encounter contemporary doxa about Plato's critique of democracy and Foucault's reception of it. Finally, any attempt to import Foucauldian genealogy into a contemporary context should be approached with caution, not least because Foucault himself generally resists such moves. ${ }^{2}$

In what follows, I argue that ethical parrhēsia on either the Socratic or Cynical model would have little critical traction today because the current social media environment is plagued by problems analogous to those Plato thought plagued Athenian democracy. Specifically, authentication of parrhesiasts as a technique for authenticating their speech - the specific problem that the move to ethical parrhessia was designed to solve - becomes intractable in a social media environment, even with the Cynical move to pure visibility. I develop the thesis along four primary lines: (1) Foucault invites the consideration of ethical parrhēsia in a contemporary context by suggesting that "militant" movements exhibit an analogous concern with authenticity. His implicature is nearly always negative. (2) In Foucault's analysis, parrhēsia has both a political and an ethical phase; the transition between them happens in Plato and is induced by what Plato perceives as problems of simulacra. Cynicism is the most radical version of the ethical phase, and involves the Cynic's self-authentication by scandalously living his life completely visibly, subject to continuous inspection. (3) Contemporary society overproduces visibility as a condition for participation, which means that the context for authenticating parrhesiastic speech is one in which visibility is banalized and in which there is a surplus of speech which presents as parrhesiastic. The problem of authentication is thus a serious

\footnotetext{
${ }^{2}$ For the argument that Foucauldian concepts should not be taken from their original contexts, see Colin Koopman, "Two Uses of Michel Foucault in Political Theory: Concepts and Methods in Giorgio Agamben and Ian Hacking," Constellations 22:4 (2015). For two otherwise very different examples of directly importing parrhessia into a contemporary context, see Michael Hardt, "The Militancy of Theory," South Atlantic Quarterly 110:1 (2011) and Zachary Simpson, "The Truths We Tell Ourselves: Foucault on Parrhesia," Foucault Studies 13 (2012). A similar argument (for an example, see Alison Ross, "Why Is "Speaking the Truth" Fearless? "Danger" and "Truth" in Foucault's Discussion of Parrhesia," Parrhesia 4 (2008)) is that the difference between our society and that of the ancient Greeks means that their practices could be used to successfully critique our own. That of course is possible, but it requires either endorsing the Greek practices or a detailed examination of how those practices might function in a very different context. Nancy Luxon, "Truthfulness, Risk, and Trust in the Late Lectures of Michel Foucault," Inquiry 47:5 (2004) usefully emphasizes the singular exemplarity of the parrhesiast (as opposed to someone who embodies a more general rule or standard), which pushes back against such abstractive tendencies, since the parrhesiast is always exemplary relative to a particular context.
} 
one. (4) Social media makes the authentication of parrhēsia increasingly difficult. On the one hand, parrhesiastic speech can easily be faked. On the other hand, and more fundamentally, power in social media works to invisibly shape subjectivity in a direction that makes critical speech very difficult. A concluding section suggests that the effort to import parrhessia into the present remains reliant on a view of subjectivity as exogenous to its social context, a view that Foucault consistently attempted to undermine.

\section{Militancy and two strands of parrhēsia}

At the end of Courage of Truth, Foucault connects his discussion of parrhessia to the development of "two major cores of Christian experience," one mystical, oriented toward "confidence in the love of God" and aligned with the parrhesiastic tradition; and the other ascetic, emphasizing "fear [of] and obedience" to God. ${ }^{3}$ The ascetic tradition is familiar; earlier in the lectures, Foucault had noted that "through the intermediary of Christian asceticism and monasticism ... the Cynic mode of life was passed on for a very long time." 4 But what of the more subaltern version of parrhēsia? Foucault characterizes this mystical, positive version as follows:

In its positive value, parrhessia appears as a sort of hinge virtue, which characterizes both the attitude of the Christian, of the good Christian, towards men, and his way of being with regard to God. With regard to men, parrhēsia will be the courage to assert the truth one knows and to which one wishes to bear witness regardless of every danger. ${ }^{5}$

Thus, he proposes, "the martyr is the parrhesiast par excellence." 6

Christianity abandons this positive version of parrhessia early on, and "this theme of parrhēsia-confidence will be replaced by the principle of a trembling obedience, in which the Christian will have to fear God and recognize the necessity of submitting to His will, and to the will of those who represent Him." 7 As Andreas Folkers puts it of this ascetic version, "speaking the truth became an exercise of rather than a challenge to power in modernity." 8 This historical moment matters in part because Foucault also claims that the ascetic renunciation of parrhēsia is a significant moment in the development of pastoral power, which he had earlier said was itself the precursor of biopower. Thus, "in Christianity, the pastorate gave rise to an art of conducting, directing, leading, guiding, taking in hand, and manipulating men ... [which] seems to me to be an important, decisive phenomenon" in the "historical background of ... governmentality." He concludes: "the modern state is born, I think, when governmentality becomes a calculated and reflective practice." 9

\footnotetext{
${ }^{3}$ Michel Foucault, The Courage of Truth (the Government of Self and Others 2): Lectures at the Collège De France, 1983-1984 [1984], ed. Arnold I. Davidson (2011), 336.

4 Ibid., 182.

5 Ibid., 331.

${ }^{6}$ Ibid., 332.

7 Ibid., 333.

${ }^{8}$ Andreas Folkers, "Daring the Truth: Foucault, Parrhesia and the Genealogy of Critique," Theory, Culture E Society (2015), 8.

${ }_{9}^{9}$ Michel Foucault, Security, Territory, Population: Lectures at the Collège De France, 1977-78 [1978] (2007), 165.
} 
Foucault's sympathies fairly clearly align with the abandoned, mystical version. As he puts it:

It seems to me that the long and difficult persistence of mysticism, of mystical experience in Christianity, is nothing other than the survival of the parrhesiastic pole of confidence in God, which, not without difficulty, has subsisted in the margins against the great enterprise of anti-parrhesiastic suspicion that man is called upon to manifest and practice with regard to himself and others, through obedience to God, and in fear and trembling before this same God..$^{10}$

Foucault is of course not making an argument for the love of God, what he is doing is finding in this subaltern parrhēsia a critical technique, in the precise sense that it practices "the art of not being governed quite so much." ${ }^{11}$ As a response to ascetic dictates of obedience, ancient Cynical practices thus "left a certain mode of life in the history of the West, a certain bios, which, in different modalities, has played a crucial role."12 On the whole, this narrative thus suggests a possible connection between ancient, pre-Christian parrhēsia and a critique of biopolitics. It also suggests that parrhēsia is vulnerable to cooption by dominant power structures.

Of course, even if its history shows its opposition to what will become biopolitics, Greek parrhēsia does not directly speak to our problems, and Foucault underscores that "you can't find the solution of a problem in the solution of another problem raised at another time by other people."13 At the same time, study of Greek parrhēsia might offer a clue as to what a renewed critical parrhesia might look like today, and what the "main danger" confronting it would be. Interestingly, Foucault seems to want us to pursue this line of inquiry. After noting that late Greek Cynicism is a form of parrhessia which "finds its instrument ... in the very life of the person who must thus manifest or speak the truth in the form of a manifestation of existence," he moves immediately to the present:

Cynicism appears as this way of manifesting the truth, of practicing alethurgy, the production of truth in the form of life. It seems to me that I have found a theme here ... which was really very important in ancient philosophy, in Christian spirituality, much less in contemporary philosophy no doubt, but certainly in what could be called political ethics since the nineteenth century: this is the theme of the true life. ${ }^{14}$

He thus cites the nineteenth-century revolutionary movement as "another support of Cynicism understood as a form of life in the scandal of the truth." ${ }^{15} \mathrm{He}$ also suggests that "you see the problem of the style of revolutionary life reappearing fairly constantly in what may be called leftism."16 In a very late interview, he makes analogous remarks

\footnotetext{
${ }^{10}$ Foucault, Courage of Truth, 337.

${ }^{11}$ Michel Foucault, "What Is Critique," [1978] in The Politics of Truth: Michel Foucault, ed. S. Lotringer and L. Hochroch (1997), 45.

${ }_{12}$ Courage of Truth, 339.

${ }^{13}$ Michel Foucault, "On the Genealogy of Ethics: An Overview of Work in Progress," [1982] in The Foucault

Reader, ed. Paul Rabinow (1984), 342.

${ }^{14}$ Courage of Truth, 217, 18.

${ }^{15}$ Ibid., 183.

${ }^{16}$ Ibid., 185.
} 
about the dependence of "recent liberation movements" on "so-called scientific knowledge" of the self, and notes he is "struck by the similarity of problems." 17

On this reading, a prominent model of resistant politics valorizes subjects who lead a "true life." Such subjects would achieve a degree of freedom in that life; living a true life would also be a precondition for resistant political action. As I will show in detail, this construction tends to elide the boundary between ethical authenticity and political ethics. The result is a blurring of questions about what a resistant subject is and what one does. Such a conflation of political action and subject position, and the risk that the latter becomes reified, is one that Foucault views his own work as bringing into question. Thus, in "Subject and Power," Foucault suggests that his work over the previous twenty years had not been to analyze power as such, but "to create a history of the different modes by which, in our culture, human beings are made subjects." 18 In Courage of Truth, he introduces his discussion of the Cynics in the context of an ambiguity he finds in Socratic parrhessia between metaphysical discourse about the soul and an ethical "stylistics of existence." He notes of the latter that "this aspect of the history of subjectivity ... has of course been hidden and overshadowed by what could be called the history of metaphysics" but that it should "not be neglected."19 As I will suggest, the risk of the move to authenticity is that ethical practices are grounded metaphysically at the expense of their political contexts.

Placing subjectivity in the context of a form of life and not a metaphysics of the soul thus requires the rejection of essentializing and reductive views of subjectivity. In "Subject and Power," Foucault proposes and rejects one such view, according to which "all types of subjection are derived phenomena, that they are merely the consequences of other economic and social processes: forces of production, class struggle, and ideological structures which determine the form of subjectivity." 20 The argument recalls his earlier dismissal of the "totalitarian" explanatory structures of Freudianism and orthodox Marxism. ${ }^{21}$ He suggests that today, we see a "tricky combination in the same political structures of individualization techniques and of totalization procedures." 22 The Cynic, for whom "the form of existence [is] an essential condition of truth-telling" such that the form of life is "the immediate, striking, and unrestrained presence of the truth" is thus of interest as presenting an earlier effort at radical resistance that engages politics indirectly at the level of individual strategies for resistant ethical stylization. ${ }^{23}$

\footnotetext{
${ }^{17}$ Michel Foucault, "On the Genealogy of Ethics: An Overview of Work in Progress," 343.

${ }^{18}$ Michel Foucault, "The Subject and Power," in Michel Foucault: Beyond Structuralism and Hermeneutics, ed. Hubert L. Dreyfus and Paul Rabinow (1982), 208.

${ }_{19}$ Courage of Truth, 162.

${ }^{20}$ Foucault, "Subject and Power," 213.

${ }^{21}$ Society Must Be Defended: Lectures at the College De France, 1975-76 [1976] (2003), 6. For a reading of the parrhesia lectures as a response to Marxism and Sartreanism, see Nancy Luxon, "Ethics and Subjectivity: Practices of Self-Governance in the Late Lectures of Michel Foucault," Political Theory 36:3 (2008). For evidence that we face similar problems with reification of critical categories today, see, e.g., Jasbir Puar's discussion of the reification of intersectionality in "“I Would Rather Be a Cyborg Than a Goddess:' BecomingIntersectional in Assemblage Theory," philoSOPHIA 2:1 (2012).

22 "Subject and Power," 213.

${ }^{23}$ Courage of Truth, 172-173.
} 


\section{Simulacra and the Impossibility of Politics}

If Foucault wants us to see a connection between contemporary militancy and ancient parrhēsia, what does he have to say about ancient parrhēsia? For the purposes of the analysis here, and although many commentators elide the distinction, it is important to note that Foucault does not treat ancient parrhèsia as a unitary phenomenon. In particular, he takes Socratic parrhèsia as liminal between an earlier, political mode and a later, ethical one. ${ }^{24}$ Thus, Socratic parrhessia is responsive to "the crisis of political parrhessia, or at least the crisis of political institutions as a possible site for parrhēsia." 25 The crisis is provoked by a question: "what makes true discourse powerless in a democracy?" 26 Foucault had earlier established the historical context for the question, noting that in the time between Pericles and Plato, one could detect the emergence of "a certain ambiguity concerning the value of parrhēsia." 27 The problem was twofold. On the one hand, the democratic practice of allowing anyone to speak raises a problem about the subjectivity of the parrhesiast insofar as "parrhesia makes it possible for the worst as well as the best to speak." 28 On the other hand, the presence of risk in parrhesiastic speech incentivizes speakers to say "what the people or the sovereign would like to hear." This produces a problem with flattery, which represents "parrhēsia's shadow, its bad and dubious imitation." 29

The full analysis of these late pre-Platonic changes in parrhesia is of course quite complex. For the sake of simplicity, I want to focus on the question of true speech and democracy in Plato. For the Greeks generally, Foucault suggests that "if democracy can be governed, it is because there is true discourse." 30 The practice of allowing anyone to speak introduces the problem of insincere flatterers. Previously, the Greeks convinced themselves that this risk had been addressed by restrictions on who was allowed to speak - "old, ancestral rights of birth and especially of belonging to the soil ... [or personal] qualities like those of Pericles." 31 The importance of these attributes is evident in Foucault's reading of Euripides' Ion, in which Ion struggles to demonstrate his lineage. However, as Lida Maxwell notes, even this is not enough to stabilize the practice: Ion also depends on the silencing of women and slaves. ${ }^{32}$

\footnotetext{
${ }^{24}$ Jakub Franěk, "Philosophical Parrhesia as Aesthetics of Existence," Continental Philosophy Review 39:2 (2006), emphasizes the move from politics to ethical parrhēsia in Courage of Truth, but uses it to parallel Foucault and Socrates: Foucault's discussion of the Socratic Apology should be read as Foucault's own apologia, and his self-presentation as an ethical parrhesiast. This is a fascinating possibility, but I also think it is unlikely. For one, it ignores the remainder of the text, which moves very quickly to Cynicism. As I will argue, the latter portions of Courage of Truth do not, I think, support an easy endorsement of ethical parrhēsia.

${ }_{25}$ Courage of Truth, 73.

${ }^{26}$ Ibid., 40.

${ }^{27}$ Foucault, Government of Self and Others, 301.

${ }^{28}$ Ibid., 302.

${ }^{29}$ Ibid.

${ }^{30}$ Ibid., 184. On the centrality of parrhēsia to democracy, see, e.g., Torben Bech Dyrberg, "Foucault on Parrhesia: The Autonomy of Politics and Democracy," Political Theory 44:2 (2016).

${ }^{31}$ Government of Self and Others, 182.

32 Lida Maxwell, "The Politics and Gender of Truth-Telling in Foucault's Lectures on Parrhesia," Contemporary Political Theory (2018). As Maxwell argues, this is a silencing that Foucault also elides.
} 
Absent these constraints, both visible and invisible, Plato thinks that, in Foucault's paraphrase, "in democracy one cannot distinguish between good and bad speakers, between discourse which speaks the truth and is useful to the city, and discourse which utters lies, flatters, and is harmful." ${ }^{33}$ Readers of Plato's Republic will immediately recall the presentation of democracy as a final corruption on the way to tyranny:

Democracy, I suppose, comes into being when the poor win, killing some of the rulers and casting out some, and share the regime and the ruling offices with those who are left on an equal basis; and, for the most part, the offices in it are given by lot .... It is probably the fairest of the regimes ... just like a many-colored cloak decorated in all hues, this regime, decorated with all dispositions, would also look fairest, and many perhaps ... like boys and women looking at many-colored things, would judge this to be the fairest regime $(557 a-c)$.

In such a context, everyone has the ability to say "what is in accord with their private will and with what will enable them to satisfy their interests and passions." 34 As Debra Nails emphasizes, it is important to read Plato's critique in its historical context. ${ }^{35}$ Athenian democracy was beset by a number of structural problems to which Plato clearly alludes; three points are most relevant here. First, citizens developed no particular skills in governing because offices were chosen by lot, and people rotated in and out of governmental tasks randomly. Second, the lawmaking Assembly was at best fickle, and was famous for reversing itself repeatedly. Finally, Plato in the Statesman (302d1-303b5) distinguishes law-governed democracies from those whose laws do not exist or have been forgotten. That is, Plato is interested in and open to ways that democracy could address the problem.

Foucault is of course not interested in whether Plato is "correct" about democracy in general or in its Athenian version; he is interested instead in what this says about Plato's view of parrhēsia. From a Platonic point of view, parrhēsia is a necessary part of any properly functioning polis, but "cannot be told in a political field defined by an absence of ethical differentiation between the subjects speaking." 36 Foucault calls this the "Platonic reversal" and suggests that "after the criticism of democracy's inability to make room for truth-telling, the Platonic reversal consists in the validation of truth-telling as the defining principle of a politeia (of a political structure, a constitution, a type of regime) from which, precisely, democracy is carefully excluded." 37 That is, on this reading of Plato, the necessity of parrhessia to a functioning polity when combined with the inability of parrhēsia to function in democracy as it was practiced in Athens shows that Athenian democracy is not a viable regime type.

That the problem is presented as one bad of imitations and indistinction, the absence of a way to distinguish good claims to parrhesia from bad ones, suggests that it is one of simulacra. As Deleuze proposes, in language clearly echoed in Foucault's discussion, the

\footnotetext{
${ }^{33}$ Courage of Truth, 40.

${ }^{34}$ Ibid., 36.

${ }^{35}$ Debra Nails, "Plato's 'Republic' in Its Athenian Context," History of Political Thought 33:1 (2012). The following description of Athenian democracy derives from Nails.

${ }^{36}$ Courage of Truth, 44.

37 Ibid., 45.
} 
Platonic forms first and above all serve a "police" function, which is "not to oppose the world of images in its entirety but to select the good images, the icons which resemble from within, and eliminate the bad images or simulacra." 38 This authenticating function is prior to the classifying one, and as he notes, "the one problem which recurs throughout Plato's philosophy is the problem of measuring rivals and selecting claimants." 39 Plato stages the difficulty in Socrates, who is tasked here with awakening not kings, but citizens to the need for veridical speech. In other words, the difficulty in sustaining political parrhessia leads, in essence, to a retreat from politics into ethics, a move that is partially accomplished by Socrates. As Foucault puts it, parrhēsia in Plato "has to address individuals at least as much as it does the whole body of citizens" in order to show them that "they must govern themselves in order to govern the city properly." 40

Foucault reads Cynicism as a radicalization of the Socratic move. Against the philosophical development of the components of a "true life," the Cynics charge, in essence, that the philosophers merely speak of such a true life, but do not live it. If pre-Socratic parrhēsia represents the bravery of speaking truth to the Assembly, and Socratic parrhessia "consists in telling people, and getting them gradually to recognize, that they do not really know what they say and think they know," the Cynics will present parrhêsia as the scandal induced by treating truth as itself a "form of life." 41 For example, philosophy treated the principle of living a pure, unalloyed life as requiring indifference to material goods; in practice, this often meant voluntarily giving them up for a time in order to be prepared for misfortune should it strike. ${ }^{42}$ For the Cynic, the indifference to material goods is practiced as "an elaboration of oneself in the form of visible poverty. It is not an acceptance of poverty; it is a real conduct of poverty." 43

At the core of the Cynic challenge is the idea that the true life, the life of one whose parrhēsia is legitimate, has nothing to hide. The Socratic parrhesiast asserts this idea as a principle, but of course such speech could be concealing a hypocrisy in how the philosopher actually lives. Accordingly, the Cynic responds "by a dramatization of this principle of non-concealment in and by life itself." 44 In short:

Cynic courage of truth consists in getting people to condemn, reject, despise, and insult the very manifestation of what they accept, or claim to accept at the level of principles. It involves facing up to their anger when presenting them with the image of what they accept and value in thought, and at the same time reject and despise in their life. This is the Cynic scandal. After political bravery and Socratic irony we have, if you like, Cynic scandal. ${ }^{45}$

That is, the move is to present one's entire life for inspection in an effort to authenticate oneself; the object is to demonstrate a "simplicity which is truth of existence [and] ... no

\footnotetext{
${ }^{38}$ Gilles Deleuze, Difference and Repetition [1968] (1994), 127.

39 Ibid., 59-60.

${ }^{40}$ Government of Self and Others, 303.

${ }^{41}$ Courage of Truth, 233-4.

42 Ibid., 257.

${ }^{43}$ Ibid., 258.

${ }^{44}$ Ibid., 253.

${ }^{45}$ Ibid., 234.
} 
possibility of deceptions being produced by the disconnection, the discrepancy between what happens and discourse, phantoms, and signs." 46

Foucault emphasizes that this "absolute visibility of the Cynic life" stands at the center of the entire Cynic practice; the true life of the Cynic is marked by its complete transparency, and in this we see its solution to the problem of political simulacra: we know the Cynic cannot be a flatterer because he has nothing to hide. ${ }^{47}$ The Cynic has no interests beyond his animal functions and visibility. Hence, not only will "Cynic public life ... be a life of blatant and entirely visible naturalness," the Cynic is also to reject the private life of the household, and "the Cynics ... reject marriage and the family, and they practice, or claim to practice, free union." 48 Together, these are flip sides of the same coin; in contemporary terms, we might say that the Cynic authenticates himself - and implicitly criticizes others for not authenticating themselves in this way - not just by denying any need for privacy, but also by living entirely in public view.

\section{Absolute visibility today}

As indicated above, Foucault suggests that the theme of a true life is manifest today, particularly in oppositional politics. The question is whether it has political traction. In other words, does living fully in view allow one to address the problem of simulacra? In what follows, I will argue that it does not. Tracing the Greek formulation of difficulties in parrhessia and efforts to resolve them instead underscores a difficulty that Foucault sees in our own political situation. Initially, one should note that Foucault forcefully argues that power functions today through enforced visibility. His critique of panopticism as a technique for ensuring the total visibility of subjects (but not of power) is wellknown. Visibility generates compliance: "it is the fact of being constantly seen, of being able always to be seen, that maintains the disciplined individual in his subjection." 49 Surveillance since Foucault has increased in both extension and intensity, to the point that current surveillance theorists prefer terms like "surveillant assemblage" or "information imperative." 50

Indeed, permanent visibility has become so normalized that it is no longer scandalous. At least, it no longer reliably creates the Cynic scandal. Indeed, subjects now often treat it as desirable, rather than punitive. The rise of reality TV presents one example, and the ways that Facebook and other social networking sites reward users who share more and more in carefully curated "games of truth" is another. Similarly, consumers are trained to give away their privacy for "free" services on the Internet. When consumers are not forthcoming, sites like Facebook routinely use deceptive policy changes and default settings to trick them into doing so anyway. Collectively, techniques such as the-

\footnotetext{
46 Ibid., 222.

47 Ibid., 254.

48 Ibid., 255, 63.

${ }^{49}$ Discipline and Punish: The Birth of the Prison [1975] (1977), 187.

${ }^{50}$ For surveillant assemblage, see Kevin D. Haggerty and Richard V. Ericson, "The Surveillant Assemblage," The British Journal of Sociology 51:4 (2000). For "information imperative," see Julie E. Cohen, Configuring the Networked Self: Law, Code, and the Play of Everyday Practice (2012). For reasons of space, I will not be discussing surveillance by government entities, though the Snowden revelations certainly indicate that the state has also adopted the view that it would be a good idea for all citizens to be fully on display, all the time.
} 
se constitute a consistent apparatus to produce compliant, market-oriented subjects who freely make themselves available for continuous inspection, and who are either resigned to it or find doing so rewarding. ${ }^{51}$ The phenomenon dates to long before social networking; for example, when performance artist Jennifer Ringley set up webcams all over her apartment and left them continuously on, the move was promptly celebrated as empowered cyborg subjectivity, and not as another example of willingly submitting to a disempowering patriarchal gaze. ${ }^{52}$ Jennicam thus functioned as an almost perfect example of cynical ethics, presenting the "scandalous banality" of Ringley's life for general inspection..$^{53}$ Importantly, Jennicam also presented an antinomy: because of the ambivalent politics of visibility, one could equally prove that the site was subversive or not subversive, with no way to know which.

Not only is visibility rewarded, privacy is penalized. Privacy looks bad; why demand privacy unless you are doing something you shouldn't? Corporate executives routinely proclaim that privacy is dead, outdated and counterproductive. For example, Sun Microsystems CEO Scott McNealy declared in 1999 that "you have zero privacy anyway. Get over it." Facebook CEO Mark Zuckerberg has repeatedly talked about his company's efforts to shape social norms in favor of more disclosure. ${ }^{54}$ Conceptual ballasting for these claims comes from theorists such as Judge Richard Posner, who argues that interest in the privacy of information is an interest in enforcing an information asymmetry in markets. ${ }^{55}$ If I apply for a job and hide a criminal record, for example, I am trying to get you to overvalue me as a potential employee by keeping you ignorant of my past. Accordingly, Posner proposes that the law should not protect such refusals to disclose, and

\footnotetext{
${ }^{51}$ For reality TV, see Peter Weibel, "Pleasure and the Panoptic Principle," in Ctrl [Space]: Rhetorics of Surveillance from Bentham to Big Brother, ed. Thomas Y. Levin, Ursula Frohne, and Peter Weibel (2002). For "games of truth," see Rob Horning, "Games of Truth," The New Inquiry (November 3, 2013). For resignation, see the discussion of recent empirical work in Nora A. Draper, "From Privacy Pragmatist to Privacy Resigned: Challenging Narratives of Rational Choice in Digital Privacy Debates," Policy E Internet 9:2 (2016). In the case of Facebook, studies show that users' privacy settings are often not set to what users think they are, presumably due to the settings' complexity. See Yabing Liu et al., "Analyzing Facebook Privacy Settings: User Expectations Vs. Reality," in Proceedings of the 2011 ACM SIGCOMM conference on Internet measurement conference (Berlin, Germany: ACM, 2011), and Michelle Madejski, Maritza Johnson, and Steven E. Bellovin, "The Failure of Online Social Network Privacy Setetings," in Columbia University Computer Science Technical Reports (2011). For Facebook's history of deceptive practices, see David C. Vladeck, "Facebook, Cambridge Analytica, and the Regulator's Dilemma: Clueless or Venal?," in Harvard Law Review Blog (April 4, 2018). For subjectification as important to privacy, see Julie E. Cohen, "What Privacy Is For," Harvard Law Review 126 (2013); my own development of the argument is in Gordon Hull, "Successful Failure: What Foucault Can Teach Us About Privacy Self-Management in a World of Facebook and Big Data," Ethics and Information Technology 17:2 (2015).

${ }^{52}$ Krissi M. Jimroglou, "A Camera with a View: Jennicam, Visual Representation, and Cyborg Subjectivity," Information, Communication \& Society 2:4 (1999); see also the more critical discussion in Jane Bailey, "Life in the Fishbowl: Feminist Interrogations of Webcamming," in Lessons from the Identity Trail: Anonymity, Privacy and Identity in a Networked Society, ed. Ian Kerr, Carole Lucock, and Valerie Steeves (2009).

${ }^{53}$ For "scandalous banality," see Courage of Truth, 232.

${ }^{54}$ For McNealy, see Polly Sprenger, "Sun on Privacy: 'Get over It,"' Wired (Jan. 26, 1999). For Zuckerberg, see Kevin Drum, "Mark Zuckerberg Does Not Like Personal Privacy," Mother Jones (April 10, 2018).

${ }_{55}$ Richard Posner, "The Right of Privacy," Georgia Law Review 12 (1978).
} 
in some cases ought to compel disclosure. ${ }^{56}$ In the meantime, the move to data collection more generally makes it unpalatable to withhold information. Apart from access to websites and the potential loss of social capital that foregoing sites such as Facebook requires, social media is increasingly important in employment. Not only do employers scrutinize social media accounts of prospective employees, they sometimes treat the lack of social media content as itself a problem. ${ }^{57}$ Similarly, access to social services is often conditional upon data collection, which is then used as a way to condition services on compliance with behavioral desiderata. The failure to use data-collecting devices can also subject someone to socioeconomic disadvantage by shutting her out of market goods which are only accessible by submitting to surveillance. ${ }^{58}$

The rise of informatics - "big data" - makes the problem worse, in part because contemporary capital has made a market out of information itself. Data is big business, primarily because it enables the visibility required for targeted marketing. Once information is commodified, data collection essentially functions as a form of original accumulation where individuals are deprived of their privacy for very little in return; this information is then sold to advertisers or data brokers. Individuals become not only consumers, but also resources. ${ }^{59}$ Bernard Harcourt concludes:

This new and emerging political economy of data has been made possible ... [partly] by a new form of power that has taught us to willingly give our information when asked, to identify ourselves, to reveal our deepest secrets, to comply with requests and ironically, in a world of private property, to never feel entitled to express private property ownership over our own identity and all this personal information. ${ }^{60}$

Big data not only magnifies the extent to which subjects can be surveilled, but also introduces new correlations and risks, new possibilities for discrimination and error. Data even makes it possible to make inferences about those who have attempted to opt-out of surveillance; Facebook collects vast amounts of data not just on users and their friends, but on non-users as well. ${ }^{1}$

As with earlier surveillance, data functions both as a strategy of control and as an economy of pleasurable ethical stylization. An example of the former is compulsory em-

\footnotetext{
${ }^{56}$ A more complete discussion would note the extent to which demands for disclosure function differentially: more transparency is demanded of the poor, women and racial minorities. See, e.g., Loïc Wacquant, Punishing the Poor: The Neoliberal Government of Social Insecurity (2009), and Dorothy E. Roberts, "Prison, Foster Care, and the Systemic Punishment of Black Mothers," UCLA Law Review 59 (2012). For the ways (often involuntary) online identification is used to attack women, see Danielle Keats Citron, Hate Crimes in Cyberspace (2014). As Maxwell notes, following the lead of a rich body of feminist literature, privacy has always been a difficult topic for the disempowered. See Maxwell, "Politics and Gender of Truth-Telling,"

${ }^{57}$ Allison Cheston, "Recruiters Say: Avoid Linkedin at Your Peril," Forbes (May 11, 2012).

${ }^{58}$ For social services, see, e.g., Virginia Eubanks, Automating Inequality: How High-Tech Tools Profile, Police, and Punish the Poor (2017). For socioeconomic disadvantage, see Jonas Lerman, "Big Data and Its Exclusions," Stanford Law Review Online 66 (2013).

${ }_{59}$ Julie E. Cohen, "The Biopolitical Public Domain: The Legal Construction of the Surveillance Economy," Philosophy \& Technology 31:2 (2017).

60 "Governing, Exchanging, Securing: Big Data and the Production of Digital Knowledge," in Big data, entreprises et sciences sociales - Usages et partages des données numériques de masse (Paris, 2014), 30.

${ }^{61}$ For data collection from non-users, see Daniel Kahn Gillmor, "Facebook Is Tracking Me Even Though I'm Not on Facebook," in Free Future (April 5, 2018).
} 
ployee wellness programs in the U.S., which condition access to healthcare on the willingness of employees to submit not just to wellness regimes, but also often to verification regimes using strategies like wearable technologies. ${ }^{62}$ Employees are involuntary placed in the position of the Cynic: not only must they attest to their compliance with appropriate norms, they must make their life itself available for inspection to validate their testimony. An example of the latter is the "quantified self" movement, which celebrates the ability of wearables to make highly granular aspects of daily life available for inspection as an emancipatory means of care for oneself and others. In other words, as Foucault had noted, liberation movements derive some of their authority from a "socalled scientific knowledge" of the self. Quantified-self technologies do not just encompass fitness; they have extended even into intimate relationships and orgasm-tracking. ${ }^{63}$ Just as in the case of JenniCam and Reality TV, voluntary submission to highly intrusive surveillance is coming to be seen positively. In a generalized regime of Cynical selfexposure, the very generalization of efforts to implement the truth "in life itself" deprives it of its scandalous character.

The preceding is not meant to be an exhaustive survey; it is meant to indicate that contemporary society overproduces visibility as a condition for participation. This has the dual effect of banalizing visibility and making it more difficult as a criterion for authenticating parrhesiastic speech. ${ }^{64}$ It is against this background that we should evaluate the possibility of importing parrhēsia into a contemporary context.

\section{The Failure of Credentialing: Return of the Simulacra}

To understand the potential role of parrhessia today, consider first the status of scientific discourse. Foucault suggests that the problem of the true life, articulated by the Cynics, has retreated because of the ability of religion and science to function as guarantors of truth. In other words, the strictures and orthodoxies of science serve the credentialing function that status-based restrictions served in pre-Socratic Athens. Foucault suggests that:

If scientific practice, scientific institutions, and integration within the scientific consensus are by themselves sufficient to assure access to the truth, then it is clear that the problem of the true life as the necessary basis for the practice of truth-telling disappears. ${ }^{65}$

Although much more would need to be said to fully establish the argument, allow me to suggest that the current epistemic status of science is paradoxically bifurcating in a way that suggests the problem of the true life should, as it has, prominently reappear.

\footnotetext{
${ }^{62}$ Gordon Hull and Frank Pasquale, "Toward a Critical Theory of Corporate Wellness," BioSocieties 13:1 (2018).

${ }^{63}$ Deborah Lupton, "Quantified Sex: A Critical Analysis of Sexual and Reproductive Self-Tracking Using Apps," Culture, Health \& Sexuality 17:4 (2015), and Deborah Lupton, "The Diverse Domains of Quantified Selves: Self-Tracking Modes and Dataveillance," Economy and Society 45:1 (2016).

${ }^{64}$ In other words, the trust relationships that Nancy Luxon, "Truthfulness, Risk and Trust," treats as central to parrhesia are difficult to obtain today. Part of the problem is the logic of capital, but it is also that the polis is now much larger than a city-state: parrhesia does not scale well.

${ }^{65}$ Courage of Truth, 235.
} 
On the one hand, the prevalence of manufactured disputes over the reliability of climate science or the safety of vaccinations suggests that science is increasingly viewed as itself an ideological construct. ${ }^{66}$ There is also substantive evidence of the corruption of the epistemic process of science. For example, Pharmaceutical companies and the Contract Research Organizations (CROs) to which they outsource clinical trials often separate drug marketing from drug efficacy. ${ }^{67}$ As Phillip Mirowski details, the agreement with the CROs is essentially that only positive results will be reported, with potentially negative trials either rapidly discontinued or suppressed. As a result, negative or adverse clinical results are never reported. Worse, CROs routinely pay doctors to put their names on the studies to apply a veneer of credibility. This ghost-writing problem is so bad that Australian litigation discovered that every issue of at least six entire journals published by Elsevier was ghostwritten. Thus, research into even the medical literature around a drug produces information the epistemic status of which cannot be judged. One of the early advocates of evidence-based medicine has declared the process "hijacked;" as Mirowksi concludes, "the line between science and advertising is consciously being blurred in pharmaceutical research." 68 This is emphatically not to claim that science was ever independent of its social context. It is however to note the perception that the boundaries between science and marketing are blurring undermines science's status as a guarantor of truth.

On the other hand, as argued in the previous section, even as the epistemic function of science is brought into question, the scientific and technological enterprise is being deployed politically as a means to ensure the continuous visibility of subjects. Although Foucault documents the extent to which governmental entities have engaged in such disciplinary regimes, the important point here, as surveillance theorists have noted, is the generalization into other spheres and the adoption of highly intrusive surveillance techniques in markets. These work to produce docile or even enthusiastic subjects who take permanent visibility as normal. The background context is thus one where the epistemic authority of scientific discourse is in decline, and where the visibility of everyone is taken as a given.

Social media then produces an information environment in which simulacra become much harder to detect. On the one hand, blurring such as that between science and marketing is representative of a broader deracination of claims of knowledge. There is radically less context by which to judge their veracity, or to assess them historically or contextually. Instead, claims of parrhēsia can serve as brand identity, a problem Foucault explicitly accuses the PCF of fomenting. ${ }^{69}$ More subtly, harvested data can also be used

\footnotetext{
${ }^{66}$ This is not a new claim, as Marxist accounts (which as Foucault notes repeatedly had their own problem with authentication) argued that bourgeois science was ideological. Of course, many blame Foucauldian studies of science for the current state of affairs. For a response, see Bruno Latour, "Why Has Critique Run out of Steam? From Matters of Fact to Matters of Concern," Critical Inquiry 30:2 (2004).

${ }^{67}$ The following derives from Philip Mirowski, Science-Mart: Privatizing American Science (2011).

${ }^{68}$ Ibid., 251. For "hijacked," see John P. A. Ioannidis, "Evidence-Based Medicine Has Been Hijacked: A Report to David Sackett," Journal of Clinical Epidemiology 73 (2016).

${ }^{69}$ Courage of Truth, 186. For other examples, see, e.g., Shannon Winnubst, Way Too Cool: Selling out Race and Ethics (2015), arguing that neoliberal celebrations of "diversity" present gender as an accessory, and have attempted to do so for race, thereby presenting people as consumers with formally equivalent models of
} 
to infer what kinds of message someone would find persuasive and when; everyone thus receives a somewhat different version of the truth..$^{70}$ For example, a leaked Facebook document showed that the company's Australian division could help advertisers to know "moments when young people need a confidence boost" and respond accordingly. ${ }^{71}$ More generally, Facebook has published research indicating that the "emotional contagion" effect - the tendency to pick up on the moods of others - works online. ${ }^{72}$ This means that the company can, and almost certainly does, curate the emotional content of users' newsfeeds to keep them on the site longer. It is perhaps worth mentioning that Facebook users can be manipulated into increased voting; in one experiment, users who got a personalized reminder to vote were slightly more likely to do so than those who did not. ${ }^{73}$ Such nudging could easily change the outcome of a close election, and could be targeted at users whose data indicated they were likely to vote a certain way. Put differently, this sort of invisible curation makes it very difficult to distinguish parrhēsia and flattery.

Moreover, if ethical parrhēsia requires that a subject speaking declare or demonstrate her commitment to norms of the "true life," such a commitment can easily be faked, undermining the Platonic requirement that there be no problem with "discourse, phantoms and signs" as concealment. ${ }^{74}$ Accounts of Russian manipulation of online media prior to the 2016 U.S. Presidential election suggest the extent of the problem. For example, approximately two-thirds of Americans get at least some of their news from social media, and nearly half of the American electorate received deliberately planted fake stories on

\footnotetext{
"coolness," erasing both the long history of White Supremacy in the U.S. and the initial, critical use of coolness by figures such as Miles Davis; and my Gordon Hull, "Cultural Branding, Geographic Source Indicators and Commodification," Theory, Culture \& Society 33:2 (2016), arguing that the attempt to apply trademark law to products with geographically specific origins (e.g., Champagne) is a resistance strategy that might inadvertently further deracinate and standardize production processes, even as it freezes them in one physical location. Branding strategies now include critique as an effort to make brand endorsements seem authentic: see Sonia K. Katyal, "Stealth Marketing and Antibranding: The Love That Dare Not Speak Its Name," Buffalo Law Review 58 (2010). Companies now routinely pay for positive online reviews, including from those with no experience with their product, David Streitfeld, "In a Race to out-Rave, 5-Star Web Reviews Go for \$5," New York Times (August 19, 2011). Companies have also been caught paying for negative reviews of competing products, Daniel Bates, "Samsung Ordered to Pay $\$ 340,000$ after It Paid People to Write Negative Online Reviews About Htc Phones," Daily Mail (Oct. 25, 2013). In sum, capital deals with the problem of simulacra by absolutizing it: everything is simulacra. Ethical militancy is simply brand loyalty; Che shirts can be purchased at Urban Outfitters.

${ }^{70}$ Maurits Kaptein et al., "Personalizing Persuasive Technologies: Explicit and Implicit Personalization Using Persuasion Profiles," International Journal of Human-Computer Studies 77 (2015).

${ }^{71}$ Sam Machkovech, "Report: Facebook Helped Advertisers Target Teens Who Feel 'Worthless,'" ArsTechnica (May 1, 2017).

${ }_{72}$ Adam D. I. Kramer, Jamie E. Guillory, and Jeffrey T. Hancock, "Experimental Evidence of Massive-Scale Emotional Contagion through Social Networks," Proceedings of the National Academy of Sciences 111:24 (2014)

${ }^{73}$ Robert M. Bond et al., "A 61-Million-Person Experiment in Social Influence and Political Mobilization," Nature 489 (2012). For some discussion, see Zeynep Tufekci, "Engineering the Public: Big Data, Surveillance and Computational Politics," First Monday 19:7 (2014).

${ }^{74}$ Courage of Truth, 222.
} 
social media in the run-up to the election. ${ }^{75}$ Thus, one "Melvin Redick of Harrisburg, Pa., a friendly-looking American with a backward baseball cap and a young daughter, posted on Facebook a link to a brand-new website," saying on June 8, 2016 that "These guys show hidden truth about Hillary Clinton, George Soros and other leaders of the US. Visit \#DCLeaks website. It's really interesting!" Of course, both Melvin Redick and the site he pointed to were complete fabrications. ${ }^{76}$ As Brett Frischmann and Evan Selinger comment:

The software posed as real people - regular folks offering earnest, special-interest-free, political opinions - and masked their real agenda of being tools designed to sway votes and circulate calculated talking points. Even though disinformation campaigns have been going on for a long time and attack ads have become a political staple, the bot situation is especially troubling. In a polarized world, when bots are designed to look and sound like us, our neighbors, and our friends, it can be hard to know who or better yet, what - is engineered to follow a deviously programmed script. ${ }^{77}$

In short, the software was designed to trick readers into believing that it was presenting truth by presenting itself as the voice of honest, trustworthy speakers. This undermines precisely the authentication strategy of Socratic parrhēsia.

It is also important to note that a substantial portion of the news was apparently designed to increase social divisions, independently of whether it benefited a specific candidate. For example, the Russian-backed Internet Research Agency tried to stoke activism both for and against Black Lives Matter. Far-right media portrayed the student survivors of the Parkland high school shooting as "false flags" and "crisis actors" in an effort to undermine their legitimacy as speakers. Outside of the U.S., fake news on social media has led to outbreaks of Buddhist-Muslim mob violence in Sri Lanka, inflamed attacks against the Rohingya in Myanmar and led to lynchings in Indonesia, India and Mexico. ${ }^{78}$ In other words, parrhesiastic speech can easily be faked and manipulated to create modern versions of the sorts of problems that Plato found in Athens.

In the present context, it is difficult to see how the Cynic move toward living the true life can help. The Cynic was able to be physically present for inspection, something which is lacking in an environment where access to speakers is primarily electronically

${ }^{75}$ Carol E. Lee and Jo Ling Kent, "Facebook Says Russian-Backed Election Content Reached 126 Million Americans," NBC News.com (Oct. 30, 2017), and Elisa Shearer and Jeffrey Gottfried, "News Use across Social Media Platforms 2017," Pew Research Center for Journalism and the Media (2017). Of course, such problems are not specific to the political sphere. For example, one recent report documents how for-profit centers have infiltrated Facebook addiction-recovery groups, channeling patents to their centers under the guise of free support. See Cat Ferguson, "Predatory Behavior Runs Rampant in Facebook's Addiction Support Groups," The Verge (May 21, 2018).

${ }^{76}$ See Scott Shane, "The Fake Americans Russia Created to Influence the Election," New York Times (Sept. 7, 2017).

77 Brett M. Frischmann and Evan Selinger, Re-Engineering Humanity (2018), 4.

${ }^{78}$ For the targeting of Black Lives Matter, see April Glaser, "Russian Trolls Were Obsessed with Black Lives Matter," Slate (May 11, 2018). For Parkland, see Matthew Yglesias, "The Parkland Conspiracy Theories, Explained," Vox (Feb. 22, 2018). For the non-U.S. examples, see Amanda Taub and Max Fisher, "Where Countries Are Tinderboxes and Facebook Is a Match," New York Times (April 21, 2018). Community leaders in Sri Lanka repeatedly claimed that Facebook did nothing in response to their pleas to remove inflammatory content. 
mediated. The problem is not that everyone curates their image on social media; after all, reports that Diogenes responded to being treated like a dog at a dinner party by urinating on the guests underscore that public personae have always been curated. ${ }^{79}$ The Cynics were aware of the perception of curation as a problem; as Foucault notes, "the criticism of Cynicism is always made in the name of an essential Cynicism." 80 The problem is one they attempted to solve by pushing curation to the point that it turned into authenticity. This is not only why they attempted to eschew any private space for themselves; it is why they also adopted and radicalized the other philosophical techniques for self-authentication by actively seeking poverty, attempting to live in accord with their animal needs alone, and asserting that they were kings (in order to expose "how hollow, illusory, and precarious the monarchy of kings is"). ${ }^{81}$ These techniques were always fragile; now that their performance can easily be fabricated, they seem completely inadequate to their assigned task of sorting through simulacra.

The background problem is partly that the strategy is premised on the idea that the visibility sought by the Cynic is both confined to the Cynic and scandalous. As we move to a regime where universal visibility is both increasingly universal and an object of curiosity and play, neither of these conditions hold. Further, the problem of curation is intensified by the increasing levels of mediation that lie between a subject and her selfrepresentation. These layers of mediation can be manipulated by speakers to authenticate themselves, but they can also be manipulated to undermine one's opponents. As Foucault quips after the "essential Cynicism" line, his audience has "seen the same phenomenon in recent years with the criticism of socialism, which could only be made in the name of socialism, an essential socialism." 82 By analogy, the solution to problems posed by visibility is presented as more visibility.

\section{Conclusion: Authenticity and Subjectification}

The preceding has outlined the depth of the difficulties parrhèsia faces in the current environment. I would like to close by suggesting that the uncritical endorsement of parrhessia in the current context tends also to uncritically adopt a dubious model of subjectivity. As I suggested in the introduction, this is a problem against which Foucault warned and that his work starts to assemble the tools to understand. His late work, in particular, is explicitly oriented to understanding the processes by which people become certain kinds of subjects, to the point that he suggests in "Subject and Power" that questions about subject-formation were what drove his research into kinds of power. Foucault's research into subjectification is particularly salient in studying how parrhēsia might function or be reclaimed today.

The deeper Foucauldian problem with the trajectory taken in later Greek parrhesiastic practices is that processes of subject-formation undermine the entire project of authentication, because it is not clear what would constitute a "true" life or even if such a thing could exist. As the decline of privacy evidenced in social media has made newly appar-

\footnotetext{
${ }^{79}$ For the urination anecdote, see Courage of Truth, 262.

${ }^{80}$ Ibid., 202.

${ }^{81}$ Ibid., 275.

82 Ibid., 202.
} 
ent, speaking subjects are substantially a product of their environments. Again, evidence from Facebook allows one to make the theoretical point concretely. The issue here is not micro-targeting, which might be conceptualized as very precise efforts to influence what existing subjects do. The issue is rather of trying to manipulate who subjects will be. Such manipulation would, among other things, be almost completely undetectable. Published research indicates both that personality traits can be predicted from an automated analysis of Facebook "likes" and that advertising targeted to personality can be much more effective than non-targeted, even if only one "like" is available for the prediction. ${ }^{83}$ The implication is that Facebook's data can be used to predict what sorts of things users might do, and to nudge them one way or another. Documents leaked in spring 2018 suggest that this is precisely what the company is doing: using various machine-learning techniques to anticipate what users will do, thereby enabling advertisers or other agents to steer them before they act. ${ }^{84}$ In a direct sense, the subjectivity of Facebook users will be in part determined by the ways that advertisers, political bots or other agents anticipate and influence their behavior.

This happens in at least three ways. First, the networking environment structures individuals' information environments. That environment determines what kinds of actions are possible, and what kinds of information are "true." If someone depends on Facebook for their news, then the "truth" of world events is whatever Facebook's newsfeed turns up. To be sure, this was a problem with mass media as well, but the deracinated bits of information that emerge in algorithmically-curated newsfeeds are there for reasons which are entirely opaque. The veracity or even identity of the speaker is nearly impossible to verify, and, unlike major newspapers, those senders often have no incentives to be who they say they are. Second, this structuring is both invisible and dynamic, in the sense that it is always modulated to respond to new information obtained about individuals. Both the dynamic modulation and the invisibility make such "hypernudges" particularly good techniques of subjectification insofar as the behaviors they incentivize are easy to habituate. Finally, insofar as the data that generates them draws from analyzable patterns, the nudges also tend to cite social norms in the process of getting subjects to iterate them. ${ }^{85}$ They thus tend to push individuals toward conformity. Tobias Matzner puts the point as follows:

Data does not only produce suspects, but also potential partners, employees and customers. Claims to truthfulness are part of this game-not its precondition as the representationalist account would have it. Data can produce impostures and transparency, show-offs and "open books," facts and lies. Here, not only the data itself is important. The very fact whether or not we appear in a particular way in digital

\footnotetext{
${ }^{83}$ Michal Kosinski, David Stillwell, and Thore Graepel, "Private Traits and Attributes Are Predictable from Digital Records of Human Behavior," Proceedings of the National Academy of Sciences 110:15 (2013), and S. C. Matz et al., "Psychological Targeting as an Effective Approach to Digital Mass Persuasion," ibid. (2017).

${ }^{84}$ Sam Biddle, "Facebook Uses Artificial Intelligence to Predict Your Future Actions for Advertisers, Says Confidential Document," The Intercept (April 13, 2018).

${ }^{85}$ For "hypernudges," see Karen Yeung, "'Hypernudge': Big Data as a Mode of Regulation by Design," Information, Communication E Society 20:1 (2017). For citation and iteration, see Tobias Matzner, "Beyond Data as Representation: The Performativity of Big Data in Surveillance," Surveillance and Society 14:2 (2016).
} 
communication - on a social networking site, in a texting service- contributes to who we are. ${ }^{86}$

It is this problem against which the authenticating practices of ethical and Cynical parrhēsia have such difficulty.

Foucault's study of the Cynics shows that ethical stylization can be critical; nobody would argue that the Cynics upheld social norms, even as he shows that the absolute visibility demanded by cynical practice comes at a very high cost. So too, outside the far right, the Parkland students were taken to be authentic and thus presenting legitimate demands, largely because they were seen as traumatized children who were difficult to interpellate as "political" actors. The account of parrhēsia thus offers a partial answer to those who complain that Foucault's work on ethics offers nothing in the way of resistance. At the same time, reading the parrhèsia lectures in the context of current patterns of social media use and of a general social focus on visibility suggests that it is important to keep in mind Foucault's larger concerns with subjectification as well. Visibility now is no longer just a critique of power; it is also an exercise of it. The pervasiveness of visibility diminishes its ability to scandalize and thereby dispossesses the Cynical strategy of much of its critical bite. In other words, that there were efforts to portray even the Parkland survivors as cynical flatterers and "crisis actors" suggests the limits to authenticity as a strategy for legitimating parrhesiastic speakers.

Those concerns imply that the strategy of Cynical parrhēsia depends on a misplaced notion of the subject as someone whose life could be purified according to an abstract standard, outside of its socio-political context. ${ }^{87}$ In other words, the idea that stylization could produce speech from a space outside of politics presupposes that such a space is available, and that techniques of stylization can be somehow apolitical in nature. In that regard, the strategy risks reverting to a "metaphysics of the soul," instead of the "aesthetics of existence" that Greek parrhesiasts tried to practice and that Foucault's lectures try to uncover ${ }^{88}$ In such a reversion, Cynicism would risk becoming "mere logos" without actually doing anything in the world. ${ }^{89}$

The historical moment of Greek Cynicism was one where truth-telling and mode of life could converge with minimal theoretical mediation:

This connecting up of truth-telling and mode of life, this fundamental, essential connection in Cynicism between living in a certain way and dedicating oneself to telling the truth is all the more noteworthy for taking place immediately as it were, without doctrinal mediation, or at any rate within a fairly rudimentary theoretical framework. ${ }^{90}$

To the extent that this convergence can now only be maintained with extensive mediation, or where simulacra interfere with its efficacy, parrhèsia requires a different founda-

\footnotetext{
${ }^{86}$ Matzner, “Beyond Data as Representation," 205.

${ }^{87}$ I thus think that analyses that emphasize the abstract idea of self-transformation are mistaken. For a recent example, see Giovanni Maria Mascaretti, "Michel Foucault on Problematization, Parrhesia and Critique," materiali foucaultiani 3:5-6 (2014).

${ }^{88}$ For the opposition, see Courage of Truth, 159-162.

${ }^{89}$ For "mere logos," see Government of Self and Others, 254.

${ }^{90}$ Courage of Truth, 165.
} 
tion. The Cynics were right to locate critique in practice, in (as Foucault describes the Greek priority) ergon and not logos. ${ }^{91}$ However, insofar as their practices depended on a specific social structure of truth, they cannot be uncritically assimilated into a context where that alethurgy is radically in question. As Foucault strongly implies, we should be wary of such efforts at assimilation, as they risk enacting a problematic view of ethical subjectivity as something somehow separable from its political context. These contexts are specific; rather than looking for a unified theoretical account of parrhessia, one is better off looking at "tools that can be used at the local level only when the theoretical unity of their discourse is thoroughly disrupted." 92

\section{References}

Bailey, Jane, "Life in the Fishbowl: Feminist Interrogations of Webcamming," in Lessons from the Identity Trail: Anonymity, Privacy and Identity in a Networked Society, ed. Ian Kerr, Carole Lucock and Valerie Steeves, 283-301. Oxford: Oxford University Press, 2009.

Barocas, Solon, and Andrew D. Selbst, "Big Data's Disparate Impact," California Law Review 104 (2016), 671-732.

Bates, Daniel, "Samsung Ordered to Pay $\$ 340,000$ after It Paid People to Write Negative Online Reviews About Htc Phones," Daily Mail, Oct. 25, 2013.

Biddle, Sam, "Facebook Uses Artificial Intelligence to Predict Your Future Actions for Advertisers, Says Confidential Document," The Intercept, April 13, 2018.

Bond, Robert M., Christopher J. Fariss, Jason J. Jones, Adam D. I. Kramer, Cameron Marlow, Jaime E. Settle, and James H. Fowler, "A 61-Million-Person Experiment in Social Influence and Political Mobilization," Nature 489 (2012), 295. https://doi.org/10.1038/nature11421

Cheston, Allison, "Recruiters Say: Avoid Linkedin at Your Peril," Forbes, May 11, 2012.

Citron, Danielle Keats, Hate Crimes in Cyberspace. Cambridge, MA: Harvard University Press, 2014.

Cohen, Julie E., "The Biopolitical Public Domain: The Legal Construction of the Surveillance Economy," Philosophy \& Technology 31:2 (2017), 213-33. https://doi.org/10.1007/s13347-017$\underline{0258-2}$

Cohen, Julie E., Configuring the Networked Self: Law, Code, and the Play of Everyday Practice. New Haven [Conn.]: Yale University Press, 2012.

Cohen, Julie E., "What Privacy Is For," Harvard Law Review 126 (2013), 1904-33.

Deleuze, Gilles, Difference and Repetition [1968]. New York: Columbia University Press, 1994.

Draper, Nora A., "From Privacy Pragmatist to Privacy Resigned: Challenging Narratives of Rational Choice in Digital Privacy Debates," Policy E Internet 9:2 (2016), 232-51. https://doi.org/10.1002/poi3.142

Drum, Kevin, "Mark Zuckerberg Does Not Like Personal Privacy," Mother Jones, April 10, 2018.

Dyrberg, Torben Bech, "Foucault on Parrhesia: The Autonomy of Politics and Democracy," Political Theory 44:2 (2016), 265-88. https://doi.org/10.1177/0090591715576082

\footnotetext{
${ }^{91}$ As Folkers puts it, Foucault "shifted the attention of theoretical self-reflections of critique from the question of the foundation of critique as a judgment of reality to scrutiny of the contingent effects of critique as an event in reality." Folkers, "Daring the Truth," 7.

${ }_{92}$ Foucault, Society Must Be Defended, 6.
} 
Eubanks, Virginia, Automating Inequality: How High-Tech Tools Profile, Police, and Punish the Poor. New York: St. Martin's Press, 2017.

Ferguson, Cat, "Predatory Behavior Runs Rampant in Facebook's Addiction Support Groups," The Verge, May 21, 2018.

Folkers, Andreas, "Daring the Truth: Foucault, Parrhesia and the Genealogy of Critique," Theory, Culture \& Society (2015). https://doi.org/10.1177/0263276414558885

Foucault, Michel, The Courage of Truth (the Government of Self and Others 2): Lectures at the Collège De France, 1983-1984 [1984], ed. Arnold I. Davidson. New York: Palgrave Macmillan, 2011.

Foucault, Michel, Discipline and Punish: The Birth of the Prison [1975]. New York: Pantheon Books, 1977.

Foucault, Michel, The Government of Self and Others: Lectures at the Collège De France, 1982-83 [1983], New York: Picador, 2008.

Foucault, Michel, "On the Genealogy of Ethics: An Overview of Work in Progress," [1982], in The Foucault Reader, ed. Paul Rabinow, 340-72. New York: Pantheon Books, 1984.

Foucault, Michel, Security, Territory, Population: Lectures at the Collège De France, 1977-78 [1978], New York: Palgrave Macmillan, 2007.

Foucault, Michel, Society Must Be Defended: Lectures at the Collège De France, 1975-76 [1976], New York: Picador, 2003.

Foucault, Michel, "The Subject and Power," in Michel Foucault: Beyond Structuralism and Hermeneutics, ed. Hubert L. Dreyfus and Paul Rabinow, 208-26. Chicago: University of Chicago Press, 1982.

Foucault, Michel, "What Is Critique," [1978], in The Politics of Truth: Michel Foucault, ed. S. Lotringer and L. Hochroch, 23-82. New York: Semiotext(e), 1997.

Franěk, Jakub, "Philosophical Parrhesia as Aesthetics of Existence," English] Continental Philosophy Review 39:2 (2006), 113-34. https://doi.org/10.1007/s11007-006-9009-2

Frischmann, Brett M., and Evan Selinger, Re-Engineering Humanity. Cambridge and New York: Cambridge University Press, 2018.

Gillmor, Daniel Kahn. "Facebook Is Tracking Me Even Though I'm Not on Facebook." In Free Future: ACLU.org, 2018.

Glaser, April, "Russian Trolls Were Obsessed with Black Lives Matter," Slate, May 11, 2018.

Haggerty, Kevin D., and Richard V. Ericson, "The Surveillant Assemblage," The British Journal of Sociology 51:4 (2000), 605-22. https://doi.org/10.1080/00071310020015280

Harcourt, Bernard E., "Governing, Exchanging, Securing: Big Data and the Production of Digital Knowledge." In Big data, entreprises et sciences sociales - Usages et partages des données numériques de masse. Paris, 2014.

Hardt, Michael, "The Militancy of Theory," South Atlantic Quarterly 110:1 (2011), 19-35.

Horning, Rob, "Games of Truth," The New Inquiry, November 3, 2013.

Hull, Gordon, "Cultural Branding, Geographic Source Indicators and Commodification," Theory, Culture \& Society 33:2 (2016). https://doi.org/10.1177/0263276415583140

Foucault, Michel, "Successful Failure: What Foucault Can Teach Us About Privacy SelfManagement in a World of Facebook and Big Data," Ethics and Information Technology 17:2 (2015), 89-101. https://doi.org/10.1007/s10676-015-9363-z

Hull, Gordon, and Frank Pasquale, "Toward a Critical Theory of Corporate Wellness," BioSocieties 13:1 (2018), 190-212. https://doi.org/10.1057/s41292-017-0064-1 
Ioannidis, John P. A., "Evidence-Based Medicine Has Been Hijacked: A Report to David Sackett," Journal of Clinical Epidemiology 73 (May 2016), 82-6.

https://doi.org/10.1016/j.jclinepi.2016.02.012

Jimroglou, Krissi M., "A Camera with a View: Jennicam, Visual Representation, and Cyborg Subjectivity," Information, Communication \& Society 2:4 (1999), 439-53.

https://doi.org/10.1080/136911899359493

Kaptein, Maurits, Panos Markopoulos, Boris de Ruyter, and Emile Aarts, "Personalizing Persuasive Technologies: Explicit and Implicit Personalization Using Persuasion Profiles," International Journal of Human-Computer Studies 77 (2015), 38-51. https://doi.org/https://doi.org/10.1016/j.ijhcs.2015.01.004

Katyal, Sonia K., "Stealth Marketing and Antibranding: The Love That Dare Not Speak Its Name," Buffalo Law Review 58 (2010), 795-849.

Koopman, Colin, "Two Uses of Michel Foucault in Political Theory: Concepts and Methods in Giorgio Agamben and Ian Hacking," Constellations 22:4 (2015), 571-85. https://doi.org/10.1111/1467-8675.12153

Kosinski, Michal, David Stillwell, and Thore Graepel, "Private Traits and Attributes Are Predictable from Digital Records of Human Behavior," Proceedings of the National Academy of Sciences 110:15 (2013), 5802-5805. https://doi.org/10.1073/pnas.1218772110

Kramer, Adam D. I., Jamie E. Guillory, and Jeffrey T. Hancock, "Experimental Evidence of Massive-Scale Emotional Contagion through Social Networks," Proceedings of the National Academy of Sciences 111:24 (June 17, 2014 2014), 8788-90. https://doi.org/10.1073/pnas.1320040111

Latour, Bruno, "Why Has Critique Run out of Steam? From Matters of Fact to Matters of Concern," Critical Inquiry 30:2 (2004), 225-48. https://doi.org/10.1086/421123

Lee, Carol E., and Jo Ling Kent, "Facebook Says Russian-Backed Election Content Reached 126 Million Americans," NBC News.com, Oct. 30, 2017.

Lerman, Jonas, "Big Data and Its Exclusions," Stanford Law Review Online 66 (2013), 55-63.

Liu, Yabing, Krishna P. Gummadi, Balachander Krishnamurthy, and Alan Mislove.

"Analyzing Facebook Privacy Settings: User Expectations Vs. Reality." In Proceedings of the 2011 ACM SIGCOMM conference on Internet measurement conference, 61-70. Berlin, Germany: ACM, 2011.

Lupton, Deborah, "The Diverse Domains of Quantified Selves: Self-Tracking Modes and Dataveillance," Economy and Society 45:1 (2016), 101-22. https://doi.org/10.1080/03085147.2016.1143726

Lupton, Deborah, "Quantified Sex: A Critical Analysis of Sexual and Reproductive SelfTracking Using Apps," Culture, Health \& Sexuality 17:4 (2015), 440-53. https://doi.org/10.1080/13691058.2014.920528

Luxon, Nancy, "Ethics and Subjectivity: Practices of Self-Governance in the Late Lectures of Michel Foucault," Political Theory 36:3 (2008), 377-402. https://doi.org/10.1177/0090591708315143

Luxon, Nancy, "Truthfulness, Risk, and Trust in the Late Lectures of Michel Foucault," Inquiry 47:5 (2004), 464-89. https://doi.org/10.1080/00201740410004269

Machkovech, Sam, "Report: Facebook Helped Advertisers Target Teens Who Feel "Worthless"," ArsTechnica, May 1, 2017.

Madejski, Michelle, Maritza Johnson, and Steven E. Bellovin. "The Failure of Online Social Network Privacy Setetings." In Columbia University Computer Science Technical Reports, 2011. 
Mascaretti, Giovanni Maria, "Michel Foucault on Problematization, Parrhesia and Critique," materiali foucaultiani 3:5-6 (2014), 135-54.

Matz, S. C., M. Kosinski, G. Nave, and D. J. Stillwell, "Psychological Targeting as an Effective Approach to Digital Mass Persuasion," Proceedings of the National Academy of Sciences (2017). https://doi.org/10.1073/pnas.1710966114

Matzner, Tobias, "Beyond Data as Representation: The Performativity of Big Data in Surveillance," Surveillance and Society 14:2 (2016), 197-210.

Maxwell, Lida, "The Politics and Gender of Truth-Telling in Foucault's Lectures on Parrhesia," Contemporary Political Theory (2018). https://doi.org/10.1057/s41296-018-0224-5

Mirowski, Philip, Science-Mart: Privatizing American Science. Cambridge, Mass.: Harvard University Press, 2011.

Nails, Debra, "Plato's 'Republic' in Its Athenian Context," History of Political Thought 33:1 (2012), 1-23.

Pasquale, Frank, The Black Box Society: The Secret Algorithms That Control Money and Information. Cambridge, MA: Harvard University Press, 2015.

Posner, Richard A., "The Right of Privacy," Georgia Law Review 12 (1978), 393-422.

Puar, Jasbir K., "“I Would Rather Be a Cyborg Than a Goddess:” Becoming-Intersectional in Assemblage Theory," philoSOPHIA 2:1 (2012), 49-66.

Roberts, Dorothy E., "Prison, Foster Care, and the Systemic Punishment of Black Mothers," UCLA Law Review 59 (2012), 1474-500.

Ross, Alison, "Why Is "Speaking the Truth" Fearless? "Danger" and "Truth" in Foucault's Discussion of Parrhesia," Parrhesia 4 (2008), 62-75.

Shane, Scott, "The Fake Americans Russia Created to Influence the Election," New York Times, Sept. 7, 2017.

Shearer, Elisa, and Jeffrey Gottfried. "News Use across Social Media Platforms 2017." Pew Research Center for Journalism and the Media, 2017.

Simpson, Zachary, "The Truths We Tell Ourselves: Foucault on Parrhesia," Foucault Studies 13 (2012), 99-115. http://dx.doi.org/10.22439/fs.v0i13.3461

Sprenger, Polly, "Sun on Privacy: 'Get over It'," Wired, Jan. 26, 1999.

Streitfeld, David, "In a Race to out-Rave, 5-Star Web Reviews Go for \$5," New York Times, August 19, 2011.

Taub, Amanda, and Max Fisher, "Where Countries Are Tinderboxes and Facebook Is a Match," New York Times, April 21, 2018.

Tufekci, Zeynep, "Engineering the Public: Big Data, Surveillance and Computational Politics," First Monday 19:7 (2014).

Vladeck, David C. "Facebook, Cambridge Analytica, and the Regulator's Dilemma: Clueless or Venal?" In Harvard Law Review Blog, 2018.

Wacquant, Loic, Punishing the Poor: The Neoliberal Government of Social Insecurity. Durham, N.C.: Duke University Press, 2009.

Weibel, Peter, "Pleasure and the Panoptic Principle," in Ctrl [Space]: Rhetorics of Surveillance from Bentham to Big Brother, ed. Thomas Y. Levin, Ursula Frohne and Peter Weibel, 206-23. Cambridge, MA: MIT Press, 2002.

Winnubst, Shannon, Way Too Cool: Selling out Race and Ethics. New York: Columbia University Press, 2015.

Yeung, Karen, "'Hypernudge': Big Data as a Mode of Regulation by Design," Information, Communication \& Society 20:1 (2017), 118-36.

https://doi.org/10.1080/1369118X.2016.1186713 
Yglesias, Matthew, "The Parkland Conspiracy Theories, Explained," Vox, Feb. 22, 2018.

Author info Gordon Hull, PhD Associate Professor Director of Center for Professional and Applied Ethics University of North Carolina at Charlotte North Carolina, USA ghull@uncc.edu 